\title{
Transactional and Interpersonal Conversation Texts in English Textbook
}

\section{Ulin Nuha}

STAIN Kudus

Getas Pejaten RT 9 RW 4 Jati Kudus

e-mail: nuha.kds@gmail.com

\begin{abstract}
In this study, The researcher analyzed the transactional and interpersonal conversation texts found in grade VIII English textbook entitled "EOS English on Sky 2" and I also analyzed the linguistic features of the transactional and interpersonal conversations in the English textbook. This study focuses on the issues of structuralfunctional approach which analyzes the speech function, structural approach which analyzes linguistic features. This is a qualitative study. In calculating the data and the final result of data percentage, quantification was used to support this study. Units of analysis in this study are moves and clauses. The conversation texts are presented in 8 units. The moves were analyzed functionally and the clauses were analyzed structurally. The result shows that the speech functions of the transactional conversation texts are $54.5 \%$ matching the standard of content, the speech functions of the interpersonal conversation texts are $2.1 \%$ matching the standard of content. The linguistic feature applied in the transactional and interpersonal conversation texts uses the linguistic feature in functional literacy level. The speech functions of conversation texts introduced in EOS English on Sky 2 for junior high school grade
\end{abstract}


VIII are less compatible with the standard of content based on the compatibility levels.

Keywords: Transactional and Interpersonal Conversation Texts, Speech Function, and Linguistic Features

\begin{abstract}
Abstrak
Dalam penelitian ini, peneliti akan menganalisis teks percakapan transaksional dan teks percakapan interpersonal yang ada di dalam buku bahasa Inggris kelas VIII yang berjudul "EOS English on Sky 2" dan juga menganalisis fitur linguistik (linguistic feature) dari percakapan transaksional maupun interpersonal dalam buku tersebut. Penelitian ini fokus pada pendekatan fungsional dan struktural yang menganalisis fungsi bicara (speech function) dan linguistic feature. Ini merupakan penelitian kualitatif. Untuk membantu dalam menghitung data dan hasil akhir prosentase data, maka digunakan kuantifikasi. Unit analisis penelitian ini adalah move dan clause. Teks percakapan dipersembahkan dalam unit 8. Move dianalisis secara fungsional dan clause dianalisis secara struktural. Hasilnya menunjukkan bahwa speech function dari teks percakapan transaksional adalah $54,5 \%$ yang sesuai dengan standar isi, speech function dari teks percakapan interpersonal adalah 2,1\% yang sesuai dengan standar isi. Linguistic feature yang diterapkan dalam teks percakapan transaksional maupun transaksional menggunakan linguistic feature pada tingkat literasi fungsional. Berdasarkan tingkat kompatibilitas, speech function dari teks percakapan yang ada dalam buku "EOS English on Sky 2 for junior high school grade VIII" kurang sesuai dengan standar isi.
\end{abstract}

Kata kunci: Transactional and Interpersonal Conversation Texts, Speech Function, and Linguistic Feature

\title{
Introduction
}

The improvement and development of foreign language in Indonesia is mostly conducted in teaching and learning process. The 
teaching-learning process of English is the branch of language education. As language education, in Indonesia English is formally taught in the levels of education. The basic rules that regulate the education in Indonesia are government regulation No 22/2003 on National Education System (Sistem Pendidikan Nasional) and No 19/2006 on National Standard of Education (Standar Nasional Pendidikan). The implementation of those regulations is socialized into the curriculum that is conducted in the teaching and learning program in each educational institution from elementary and secondary schools to college.

Basically, the Indonesian government through the Ministry of Education has attempted to improve the quality of language teaching. In the last two decades, in terms of English teaching, the attempt has resulted in several curricula. Some of them are the curriculum of 1994 implemented in 1994 to 2003, competency-based curriculum (KBK or Kurikulum Berbasis Kompetensi) implemented in 2004 and 2005, and school-based curriculum (KTSP or Kurikulum Tingkat Satuan Pendidikan).

Recently, there are many English textbooks widely published and distributed both in junior and senior high schools. Those textbooks themselves claim to have conformed with the arrangement of KTSP. Most of the teachers often use the textbooks as handbooks without paying attention to the core of the textbooks. The question is whether the textbooks published and distributed really conform to those of KTSP's arrangement based on the regulation of the Ministry of Education. In this study, I will discuss the Englis textbook based on the national standard of education implemented in junior high school. The English textbook that 
will be anailyzed is about the transactional and interpersonal coversation texts at junior high school grade VIII.

The statement of the problem in this study is formulized in the following research questions : To what extent does the transactional conversation in EOS English on Sky 2 match Speech Function of the standard of content (Standar Isi)?, to what extent does the interpersonal conversation in EOS English on Sky 2 match Speech Function of the standard of content (Standar Isi)?, how do the linguistic features serve the communicative purposes in the conversation texts?

\section{Discussion}

The regulation of Ministry of Education No. 22/2006 explains the standard of content (Standar Isi) for elementary and high school levels. This regulation is a basic guide for the implementation of school-based curriculum (KTSP or Kurikulum Tingkat Satuan Pelajaran). The discussion of this study is to find out speech function and linguistic features of the transactional and interpersonal conversation texts that are used in grade VIII suggested by the standard of content.

For junior high school, the teaching or learning process is aimed at bringing the students to the functional literacy level so they can communicate orally and literally to overcome the daily problems. Especially for English lesson, the objectives in the teaching or learning process according to the standard of content are that the students will have ability in:

a. improving their communicative competence orally and literally to reach the functional level; 
b. understanding the importance of English to increase their ability in global competition;

c. raising their understanding for the relationship between language and culture (Standar Kompetensi dan Kompetensi Dasar Bahasa Inggris, 2006).

\section{Language Competency}

The language competency revealed by the standard of content for elementary and high schools refers to the model suggested by CelceMurcia, Dornyei, and Thurrell (1995) which is compatible with the assumption that language is communication, rather than a set of rules. Therefore, the model of competency suggested in this curriculum is a model that encourages junior high school students to communicate in English. This model is called communicative competence by CelceMurcia et al. (1995).

\section{Levels of Literacy}

The standard of content follows Weel's opinion (1987) on the different development of literacy levels among the leaners. It is stated that there are four levels of literacy: performative, functional, informational, and epistemic levels. In the level of performative, people are able to read and write; within the level of functional, people are able to use the language to meet their daily necessities, such as reading newspaper, manuals, magazines, etc. Within the level of informational. people are supposed to be able to use the language to access knoeledge they study; and within the level of epistemic, people are supposed to be able to transfer their knowledge in the foreign language they study. In 
terms of the literacy levels, Hammond et al. (1992) illustrates them clearly as follows:

\section{Levels of Literacy Suggested by Wells in Hammond (1992: 11)}

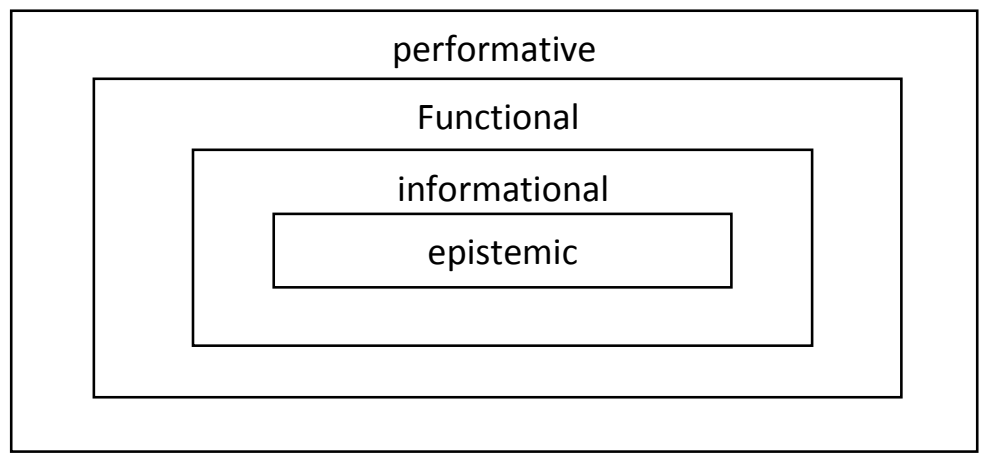

Figure 1. Indicators of Speaking Competency in the Standard of Content

The indicators of speaking teaching materials suggested by the standard of content are supposed to be able to conduct various speech acts in transactional and interpersonal spoken discourses such as asking for service, giving service, refusing service, asking for things, giving things, refusing things, admiting facts, denying facts, and asking for opinion and giving opinion; inviting, accepting, and refusing offer, agreeing or not agreeing, praising and giving congratulation; asking for service, giving/refusing services, asking for things, giving things, asking for information, giving/denying information, admiting opinion, asking for opinion, giving opinion, and offering/accepting/refusing things; asking for agreement and giving agreement, responding statement, giving attention to speaker, starting and lengthening, and closing telephone conversation. 


\section{Transactional and Interpersonal Conversations}

Transactional conversation is conducted for the purpose of information exchange, such as information-gathering interviews, role plays, or debates. It is an interaction which has an outcome, for example, buying something in a shop, enrolling in a school. In such contexts the range of language used is relatively limited and therefore reasonably predictable because speaking happens in real time and is often characterized by unfinished utterances, reformulation, overlapping utterances, grammatically incorrect utterances.

Participants must follow cultural conventions which include factors such as gesture, body language and facial expression. Decisions have to be made about the direction of the exchange and how to deal with unexpected difficulties. Speech events differ from each other according to characteristics such as the degree of distance, formality, spontaneity and reciprocity. For example, a job interview would be characterized by distance, formality, some reciprocity and relatively little spontaneity. At the other extreme, meeting someone informally for the first time is reciprocal and spontaneous. However, even those events which seem spontaneous can in fact be predictably organized and do incorporate set phrases. So, greetings, introductions and conclusions follow predictable lines. Students at this level need to be made aware of conventions of transactional exchanges and introduced to the particular language which they might expect to hear and use.

While interpersonal conversation is to establish or maintain social relationships, such as personal interviews or casual conversation role plays. According to Celce-Murcia, interpersonal conversations are usually used to express : (Celce-Murcia et. al. 1995) 
a. Greeting and leave-taking

b. Making introductions, identifying oneself

c. Extending, accepting and declining invitations and offers

d. Making and breaking engagement

e. Expressing and acknowledging gratitude

f. Complimenting and congratulating

g. Reacting to the interlocutor's speech

h. Showing attention, interest, surprise, sympathy, happiness, disbelief, disappointment.

This conversation can be done to fulfill the social interaction to the society like in socialization. The topic is free and people just produce the talk to involve in the community.

\section{Communicative Competence}

One can communicate each other by using language. He can catch our idea after we express it by language, spoken or written but it is not so simple. To be able to communicate in a language, one should know the communicative competence such as the ability how to use the linguistic system effectively and appropriately. As quoted by Celce-Murcia, et. al (1995) from Widdowson (1978) and Savigon (1983, 1990), communicative competence can be used as the basis of communicative language teaching (CLT) implicitly or explicitly.

\section{Actional Competence}

The competences developed by Celce-Murcia above are very important but the actional competence has more important rule and more 
closely related to this study. It is closely related to oral communication. Therefore, I would better discuss it in this sub chapter.

As mentioned above that Celce-Murcia, et. al (1995) defined actional competence as the competence to convey and understand communicative intent by performing and interpreting speech acts and speech act sets. It means that actional competence is quite needed by the learners to accomplish the communicative functions of language. It is normally a prime objective of the language teacher to encourage the learners to develop natural conversation skills in the target language.

Then, in order to be able to use language functions in context, language learners need to be familiar with how individual speech acts are integrated into the higher levels of the communication system. CelceMurcia divides the actional competence into two main components. They are knowledge of language function and knowledge of speech act sets. The components of actional competence are presented below.

\section{Speech Function}

Eggins and Slade (1997 ) say that speech function is the functional analysis that tries to find what purposes the utterances are expressed, and the relationship between interactants in a situation, particularly in terms of the distribution of power among the interactants

\section{Speech Function Classes}

It is necessary to classify the speech functions based on the situations in which they are used, in oredr to capture the speech function types. Speech function classes in casual conversation according to Eggins and Slade (1997: 192) are defined not only functionally but also 
grammatically in terms of predictable selections of mood and modality, semantically in terms of predictable appraisal and involment choices. They can be analyzed from the move.

The speech function classes, in subsequent, are presented in figure 4 . It can be seen that basically there are two types of move, they are opening move amd sustaining move. The each move is developed into many branches of move.

\section{Opening Move}

This move is used to begin conversation around proposition. It involves a speaker in proposing terms for interaction. It is indicating a claim to a degree of control over the interaction, and is not dependent on previous move because it is the first move in conversation. There are two classes of opening moves, attending and initiating moves. Attending moves, as said by Eggins and Slade (1997: 193), include salutations, greeting, and calls, e.g.: "How are you?", whereas, initiating moves which are used to initiate a conversation can have various functions, to offer, e.g.: “Candies?”, to command, e.g.: "Listen!”, to give (opinions and factual information), e.g.: I saw him going alone", and to ask questions (about facts and opinions), e.g.: "What can I do for you?".

\section{Sustaining Move}

This move functions to keep negotiating the same proposition. It can be conducted either by the speakers who has just been talking (continuing speech functions), or by other speakers who take a turn (reacting speech functions). Sustaining moves can be divided into two types of moves, continuing and reacting moves. 


\section{Linguistic Features}

The linguistic features that are used in grade VIII English textbook according to standard of content depend on the target in the teaching and learning process. The target of the learning process in grade VIII of junior high school students is that the students can reach functional level which make them able to communicate orally to solve their daily activities. Wells (1987) calls functional as he states that this perspective emphasyses the uses that are made of literacy in interpersonal communication. To be literate, according to this perspective, is to be able as a member of that particular society to cope with demands of everyday life that involve written language.

According to Eggins and Slade (1997) There are four main types of linguistic pattern which contribute to the achievement of conversation : grammatical, sematic, discourse and generic patterns. Grammatical patterns are revealed by studying the types of clause structures chosen by interactants and are displayed within each speaker's turns. The major grammatical resource which English offers for making these interpersonal meaning : the clause system of mood. We will show how the analysis of mood choices in conversation can reveal tensions between equality and difference as interactants enact and construct relations of power through talk.

\section{Mood in Conversation}

At the clause level, the major patterns which enact roles and role relations are those of mood, with the associated subsystems of polarity and modality. Mood refers to the patterns of clause types, such as 
interrogative, imperative and declarative. These patterns have to do with the presence and configuration of certain 'negotiable' elements of clause structure. Polarity is concerned with whether clause elements are asserted or negated, while modality covers the range of options open to interactants to temper or qualify their contributions (Eggine and Slade, 1997:74).

Mood Classification, Eggine and Slade (1997: 75)

\begin{tabular}{|c|l|l|}
\hline No & \multicolumn{1}{|c|}{ Mood Types } & \multicolumn{1}{c|}{ Example } \\
\hline 1 & Declarative : full & He plays the guitar. \\
2 & Declarative : elliptical & This year. \\
3 & Imperative : full & Look at this man ! \\
4 & Imperative : elliptical & Look ! \\
5 & Wh-interrogative : full & When are you gonna do...? \\
6 & Wh-interrogative : elliptical & Who ? \\
7 & Polar interrogative : full & Yeah but what is it ? \\
8 & Polar interrogative : elliptical & Does he ? \\
9 & Exclamative : full & What rubbish you talk, Brad ! \\
10 & Exclamative : elliptical & What rubbish ! \\
11 & Minor & Right \\
\hline
\end{tabular}

\section{Basic Clause Constituents}

Each mood type involves different configuration of a set of basic clause constituents. Full English clauses, that is clauses which have not had any elements left out or ellipse. They generally consist of two pivotal constituent : a Subject and a Finite. In addition to these pivotal constituents, (Eggins and Slade, 1997: 75) also generally find a Predicator, and some combination of Complements or Adjuncts. Below they briefly define and exemplify each of these elements, indicating their typical functions in conversation. 


\section{Research Methodology}

In this study it was conducted the structural and functional analyses on the conversation texts in the textbook entitled "Eos English on Sky 2" for junior high school students year VIII. Subsequently the texts were divided into transactional and interpersonal conversations. The units that were analyzed are moves and clauses. One move usually comprises more than one clause. The clauses are then analyzed based on theory suggested by Eggins and Slade (1997) about structural-functional approach. This approach is relevant to be applied to two major approaches, structural and functional analysis. Structural analysis was applied to analyze the linguistic features in the conversation texts. Functional analysis on the other hand, was conducted to find out speech function of every clause in conversation text.

\section{Qualitative Analysis}

Qualitative analysis in this study as explained above was applied to interpret and compare speech function contained in mood system of every clause to indicator in the standard of content and to interpret linguistic feature contained in mood system of every clause based on the standard of content. In this study, quantification was applied to support qualitative analysis in calculating data. The use of "Quantification" is the term that was especially applied to calculate numerical data obtained from structural analysis such as linguistic feature elements in the conversation texts, and to calculate the final result of the speech function comparison between the conversation texts in Eos English Sky 2 and indicators in the standard of content. 
Data refer to a collection of facts usually collected as the result of experience, observation or experiment, or processes within a computer system, or a set of premises. This may consist of numbers, words, or images, particularly as measurements or observations of a set of variables. Data is often viewed as a lowest level of abstraction from which information and knowledge are derived (Wikipedia.com). The data of this study are the total number of the written conversation texts were taken from 8 units presented in the textbook, EOS English on Sky 2 for junior high school students year VIII.

\section{Unit of Analysis}

The term of unit of analysis is also explained by Suzana and Helen (2002), according to them unit of analysis is what a researcher will collect data or observations in order to answer their research question (Suzana and Helen, 2002: 1). Dealing with the unit analysis oh this study, Halliday (1994) suggests that the discourse patterns of speech function are expressed through moves. He explains that dialogue sets up speech function as a separate discourse level of analysis, expressed through grammatical pattern. The grammatical pattern is clause. Moves and clauses do not relate to each other in terms of size or constituency. Moves are not made up of clauses and clauses are not parts of moves. The relationship is one of expression, or more technically realization, moves which are discourse units, are expressed in language through clauses, which are grammatical units. The units of analysis of this study were moves and clauses.

This study was conducted in March 2012. The data analyzed were collected with the following processes: 
1. Reading the materials of the English textbook

2. Classifying the sub-materials of speaking

3. Typing the conversation texts as the sub-materials of speaking

4. Coding the Texts

5. Segmenting the conversation texts into speech function and linguistic features.

6. Providing moves and clauses as the data analysis of speech function and linguistic features

The data of each analysis were provided in a set of file and then they were encoded based on the purpose of analysis. Each number of the text was encoded by mentioning the unit, number of text and page from the English textbook:EOS English on Sky 2.

\section{Compatibility Levels}

The result of speech function analysis was compared to the indicators stated in the standard of content. From the comparison, it could be drawn that some clauses are compatible with the standard of content and the rest are not. They were calculated to find out percentage to which conversation texts presented in the EOS English on Sky 2. The standard of compatibility levels were used to conclude the final result of the comparison among the speech functions in the textbook, EOS English on Sky 2 and the indicators in the standard of content refers to semantic differential scale suggested by Osgood in Kerlinger's (1973).

\section{Compatibility Levels of Conversation Texts}

\begin{tabular}{|c|l|l|}
\hline No & \multicolumn{1}{|c|}{ Percentage (\%) } & \multicolumn{1}{c|}{ Level } \\
\hline 1 & $0-25$ & Not compatible \\
\hline 2 & $26-50$ & Low compatible \\
\hline 3 & $51-75$ & Less Compatible \\
\hline
\end{tabular}




\begin{tabular}{|l|l|l|}
\hline 4 & $76-100$ & Compatible \\
\hline
\end{tabular}

\section{Discussion}

The functional analysis on the English textbook was conducted on the clauses of which the speech function are compatible with the indicators of the standard of content. From the analysis, it can be found that there are 40 conversation texts which consist of 111 moves and 143 clauses in EOS English on Sky 2. There are 34 texts presented in the transactional conversations, one text presented in the interpersonal conversations and 5 texts presented in both transactional and interpersonal conversations.

From the functional analysis, there are 111 moves containing 143 clauses which are compared to the speech function introduced in the standard of content. There are 105 clauses which are compatible with the indicators introduced in the standard of content and there are 38 clauses which are not compatible with any indicators introduced in the standard of content.

\section{Linguistic Features}

The structural analysis was conducted to find out the types of mood. From the analysis, it can be found that the mood types presented in the conversations are

- 67 declarative full types;

- 18 declarative elliptical types;

- 2 imperative full types;

- 1 imperative elliptical type;

- 21 wh-interrogative full types; 
- 1 wh-interrogative elliptical type;

- 19 polar interrogative full types; and

- 23 minor types.

The structural analysis in this study was also conducted on basic clause constituents. A set of basic clause constituents can be found from the full clauses which have two pivotal constituents, a subject and a finite, and in addition to these pivotal constituents, there are also a predicator, and some combinations of complements or adjuncts. From the analysis, it can be found that there are:

\begin{tabular}{|l|}
\hline $\begin{array}{l}22 \text { clauses with a set of basic clause constituent: subject, finite and } \\
\text { complement; }\end{array}$ \\
\hline 10 clauses with subject and finite; \\
\hline 14 clauses with subject, finite, predicator and complement; \\
\hline 13 clauses with subject, finite or predicator, and complement; \\
\hline 2 clauses with subject, finite and predicator; \\
\hline 5 clauses with subject, finite, complement and circumstantial adjunct; \\
\hline 2 clauses with subject, finite, complement and interpersonal adjunct; \\
\hline-5 clauses with subject, finite and circumstantial adjunct; \\
\hline - 5 clauses with subject, finite or predicator and circumstantial adjunct; \\
\hline-1 clause with subject, finite, predicator, complement and \\
interpersonal adjunct; \\
\hline - 1 clause with subject and finite or predicator; \\
\hline $\begin{array}{l}5 \text { clauses with subject, finite or predicator, complement, and circumstantial } \\
\text { adjunct; }\end{array}$ \\
\hline 1 clause with subject, finite or predicator, complement and interpersonal \\
adjunct; \\
\hline 2 clauses with subject, finite and textual adjunct; \\
\hline - 1 clause with subject, finite, predicator, and textual adjunct; \\
\hline-7 clauses with subject, finite, predicator and circumstantial adjunct; \\
\hline 7 clauses with subject, finite, predicator, complement and circumstantial \\
adjunct; \\
\hline 1 clause with subject, finite, predicator, complement and textual adjunct; \\
\hline $\begin{array}{l}1 \text { clause with subject, finite, complement, textual adjunct and circumstantial } \\
\text { adjunct, }\end{array}$ \\
\hline 1 clause with subject, finite, predicator, complement, circumstantial adjunct, \\
and textual adjunct, and \\
\hline $\begin{array}{l}\text { adjunct } \text { clause with subject, finite, complement, circumstantial adjunct interpersonal } \\
\text { adjunct }\end{array}$ \\
\hline
\end{tabular}




\section{Conclusions}

After having conducted the analysis on speech function and linguistic features in EOS English on Sky 2, some conclusions can be presented as follows

1. The transactional conversations found in the English textbook, EOS English on Sky 2 for Junior High School grade VIII are 34 texts or $85 \%$ from the total number of conversation texts. $54.5 \%$ of speech functions of the transactional conversation texts match the standard of content.

2. The interpersonal conversation found in the English textbook is only 1 text or $2.5 \%$ from the total number of conversation texts. The speech functions of the interpersonal conversation texts are $2.1 \%$ which match the standard of content. Meanwhile, the combination of both transactional and interpersonal conversations are 5 texts or $12.5 \%$ from the total number of conversation texts. $16.8 \%$ of speech functions of the interpersonal conversation texts match the standard of content.

3. The linguistic feature applied in the transactional and interpersonal conversation texts uses the linguistic feature in functional literacy level. The speech functions of conversation texts introduced in EOS English on Sky 2 for junior high school grade VIII are less compatible with the standard of content based on the compatibility levels. 


\section{References}

Celce-Murcia M, Dornyei Z, Thurrell S. 1995. Communicative Competence: A Pedagogical Motivated Model with Content Specifications. Issues in Applied Linguistics, 6 (2), 5 - 35.

Cohen, A. 1996. Developing the ability to perform speech acts. "Studies in Second Language Acquisition, 18" (2), 253-267.

Eggins and Slade. 1997. Analysing Casual Conversation in Advances in Spoken Discourse Analysis. Malcolm Coulthard (ed). London: Routledge.

Halliday, M.A.K and Hasan. 1976. Cohesion in English. London: Longman.

Halliday , M.A.K., and Hasan, R. 1989. Language, context, and text: Aspect of languagein a social semiotic perspective. Victoria: Deakin University.

Halliday, M.A.K. 1994. An Introduction to Functional Grammar. London: Edward Arnold.

Hammond, J., Burns, A., Joyce, H., Brosnan, D., Gerot, L. 1992. English for Social Purposes; A Handbook for Teachers of Adult Literacy. Sydney: Macquarie University.

Kerlinger, F.N. 1973. Foundation of Behavioral Research. $2^{\text {nd }}$ ed. New York: Holt, Reinhart and Winston Inc.

Kern, R. 2000. Literacy and Language Teaching. Hongkong: Oxford University Press.

Mayring, Ph. 2000. Qualitative Content Analysis. Retrieved April 4 2007, from http;//www.qualitative-research.net/fqs-texte/2-00/200mayring-e.htm

Mukarto. 2007.EOS English on sky 2; for junior high school students year VIII." Jakarta: Erlangga.

Nunan, D. 1992. Research Methods in Language Learning. Cambridge: Cambridge University Press.

Nunan, D. 1993. Introducing discourse analysis. England: Penguin English.

Panduan Penyusunan KTSP Jenjang Pendidikan Dasar dan Menengah 2006, Jakarta: BNSP

Peraturan Menteri Pendidikan Nasional no 11 Tahun 2005 tentang Buku Teks Pelajaran. 2005. Bandung: Diperbanyak oleh Fokusmedia.

Peraturan Pemerintrah Nomor 19 Tahun 2005 tentang Standar Nasional Pendidikan Tahun 2005.2005. Bandung: Diperbanyak oleh Fokus media. 
Richards, J. 2001. Curriculum Development in Language Teaching. Cambrigde: Cambridge University Press.

Tuckman, B.W. 1978. Conducting Educational Research. New York: HBJ Publishers.

Undang-Undang No 20 Tahun 2003 tentang Sistem Pendidikan Nasiona. 2005. Bandung: Diperbanyak oleh Fokusmedia .

Weels,G. 1987 . Apprenticeship in Litarcy. In Interchange 18, 1/2: 109123.

Widdowson, H.G. 1978. Aspect of Language Teaching. Oxford: Oxford university Press.

Wikipedia Encyclopedia. 2007. www.wikipedia.com

Wikipedia Data. 2008. http://www.answers.com/topic/data Brown, H.D. 1994. Teaching by principles: an interactive approach to language pedagogy. Englewood Cliffs, NJ: Prentice Hall Regents. 